\title{
Spectroscopic Properties and Crystal Structures of Luminescent Linear Tri- and Tetra-nuclear Gold(I) Complexes with Bis(diphenylphosphinomethyl)phenylphosphine Ligand $\dagger$
}

\author{
Dan Li, ${ }^{a}$ Chi-Ming Che, ${ }^{* a}$ Shie-Ming Peng, ${ }^{b}$ Shiuh-Tzung Liu, ${ }^{b}$ Zhong-Yuan Zhou, ${ }^{c}$ \\ and Thomas C. W. Mak ${ }^{c}$ \\ a Department of Chemistry, The University of Hong Kong, Pokfulam Road, Hong Kong \\ ${ }^{b}$ Department of Chemistry, National Taiwan University, Taipei, Taiwan \\ ${ }^{c}$ Department of Chemistry, The Chinese University of Hong Kong, Shatin, New Territories, Hong Kong
}

\begin{abstract}
Reaction of $\left[\mathrm{AuCl}_{4}\right]^{-}$with 2,2'-thiodiethanol in methanol generated $\mathrm{Au}^{\prime}$ in situ, which reacted with bis(diphenylphosphinomethyl)phenylphosphine (dpmp) and $\mathrm{NaSCN}$ to give $\left[\mathrm{Au}_{4}(\mathrm{dpmp})_{2}(\mathrm{SCN})_{2}\right]^{2+}$ and $\left[\mathrm{Au}_{3}(\mathrm{dpmp})_{2}\right]^{3+}$. The crystal structures of $\left[\mathrm{Au}_{4}(\mathrm{dpmp})_{2}(\mathrm{SCN})_{2}\right][\mathrm{SCN}] \mathrm{Cl}$ and $\left[\mathrm{Au}_{3}(\mathrm{dpmp})_{2}\right][\mathrm{SCN}]_{3}$ have been determined: $\left[\mathrm{Au}_{3}(\mathrm{dpmp})_{2}\right][\mathrm{SCN}]_{3}$, monoclinic, space group $P 2_{1} / n, a=12.474(4), b=$ 25.575(4), $c=20.182(6) \AA, \beta=92.61(3)^{\circ}$ and $Z=4 ;\left[\mathrm{Au}_{4}(\mathrm{dpmp})_{2}(\mathrm{SCN})_{2}\right][\mathrm{SCN}] \mathrm{Cl}$, space group $P \overline{1}$ (no. 2), $a=13.799(2), \quad b=14.061(2), c=19.390(4) \quad \AA, \alpha=88.46(2), \quad \beta=75.41(1), \gamma=$ $74.58(1)^{\circ}$ and $Z=2$. They comprise nearly linear $\mathrm{Au}_{3}$ and $\mathrm{Au}_{4}$ chains with $\mathrm{Au}-\mathrm{Au}-\mathrm{Au}$ angles of $167.21(2)^{\circ}$ for $\left[\mathrm{Au}_{3}(\mathrm{dpmp})_{2}\right][\mathrm{SCN}]_{3}, 160.0(1)$ and $167.2(1)$ for $\left[\mathrm{Au}_{4}(\mathrm{dpmp})_{2}(\mathrm{SCN})_{2}\right][\mathrm{SCN}] \mathrm{Cl}$. $\mathrm{A}$ weak $\mathrm{Au}^{\prime}-\mathrm{Au}^{\prime}$ bonding interaction is anticipated in view of the intramolecular $\mathrm{Au}$... Au separations. Both complexes show room-temperature photoluminescence. The red shift in the $d_{\sigma} . \rightarrow p_{\sigma}$ transition energy from $\left[\mathrm{Au}_{2}(\mathrm{dppm})_{2}\right]^{2+}[\mathrm{dppm}=$ bis(diphenylphosphino)methane $]$ to $\left[\mathrm{Au}_{3}(\mathrm{dpmp})_{2}\right]^{3+}$ and to $\left[\mathrm{Au}_{4}(\mathrm{dpmp})_{2}(\mathrm{SCN})_{2}\right]^{2+}$ has been attributed to the bonding interactions between adjacent $\mathrm{P}_{2} \mathrm{Au}$ units. The photophysical properties of $\left[\mathrm{Au}_{3}(\mathrm{dpmp})_{2}\right][\mathrm{SCN}]_{3}$ are discussed.
\end{abstract}

\begin{abstract}
The novel photophysical and photochemical properties of polynuclear $\mathrm{d}^{10}$ metal complexes have received considerable attention in our laboratory. ${ }^{1}$ Although the photophysical properties of luminescent dimeric gold(I) complexes have been studied extensively, ${ }^{a, 2-4}$ related studies on corresponding triand tetra-meric complexes are sparse. The ligand bis(diphenylphosphinomethyl)phenylphosphine (dpmp) has previously been employed to construct luminescent trinuclear metal complexes such as $\left[\mathrm{Rh}_{3}(\mathrm{dpmp})_{2}(\mathrm{MeCN})_{6}\right]^{2+} \mathbf{1}^{5}\left[\mathrm{Ag}_{3}(\mathrm{dpmp})_{2^{-}}\right.$$\left.(\mathrm{MeCN})_{2}\left(\mathrm{ClO}_{4}\right)\right]^{+} 2,{ }^{1 \mathrm{c}}$ and $\left[\mathrm{Cu}_{3}(\mathrm{dpmp})_{2}(\mathrm{MeCN})_{2}(\mu-\mathrm{X})_{2}\right]^{+} 3$ $(\mathrm{X}=\mathrm{Cl}$ or $\mathrm{I}){ }^{1 e}$ Herein is described the synthesis, crystal structure and spectroscopic properties of a linear trimeric gold(I) complex $\left[\mathrm{Au}_{3}(\mathrm{dpmp})_{2}\right][\mathrm{SCN}]_{3}$. A tetrameric complex $\left[\mathrm{Au}_{4}(\mathrm{dpmp})_{2}(\mathrm{SCN})_{2}\right][\mathrm{SCN}] \mathrm{Cl}$, which was obtained as a side product of the reaction, has also been characterized by $\mathrm{X}$-ray crystallography.
\end{abstract}

\section{Experimental}

The salt $\mathrm{K}\left[\mathrm{AuCl}_{4}\right]$ (Johnson Matthey Chemicals) and 2,2'thiodiethanol (Strem Chemicals) were used without further purification. The ligand dpmp was prepared by a published method. ${ }^{6}$ The salt $\left[\mathrm{Au}\left(\mathrm{PPh}_{3}\right)_{2}\right]\left[\mathrm{CF}_{3} \mathrm{SO}_{3}\right]$ was prepared by metathesis of $\left[\mathrm{Au}\left(\mathrm{PPh}_{3}\right)_{2} \mathrm{Cl}\right]^{7}$ with $\mathrm{Ag}\left[\mathrm{CF}_{3} \mathrm{SO}_{3}\right]$ in acetone followed by precipitation with diethyl ether. Acetonitrile (Ajax AR) was distilled over $\mathrm{KMnO}_{4}$ and $\mathrm{CaH}_{2}$ under nitrogen. Solvents for synthesis were of analytical quality used without further purification.

Synthesis of $\left[\mathrm{Au}_{3}(\mathrm{dpmp})_{2}\right][\mathrm{SCN}]_{3}$. - 2,2'-Thiodiethanol $(0.5$ $\mathrm{cm}^{3}$ ) was added with stirring to a methanolic solution of

† Supplementary data available: see Instructions for Authors, J. Chem. Soc., Dalton Trans., 1993, Issue 1, pp. xxiii-xxviii.
$\mathrm{K}\left[\mathrm{AuCl}_{4}\right]\left(0.2 \mathrm{~g}, 0.53 \mathrm{mmol}\right.$ in $10 \mathrm{~cm}^{3}$ methanol). Solid dpmp $(0.18 \mathrm{~g}, 0.36 \mathrm{mmol})$ was added when the solution became clear and colourless. The solution was heated to $40-50{ }^{\circ} \mathrm{C}$ for $0.5 \mathrm{~h}$, then NaSCN $(0.05 \mathrm{~g}, 0.62 \mathrm{mmol})$ was added to give a clear yellow solution. Yellow crystals were obtained upon standing of the solution in air at room temperature for a few days. The product was recrystallized from hot methanol (Yield $\approx 60 \%$ ) (Found: C, 44.80; H, 3.10; N, 2.30. Calc. for $\mathrm{C}_{67} \mathrm{H}_{58} \mathrm{Au}_{3} \mathrm{~N}_{3} \mathrm{P}_{6} \mathrm{~S}_{3}$ : $\mathrm{C}, 45.25 ; \mathrm{H}, 3.25 ; \mathrm{N}, 2.35 \%) ; \mathrm{v}(\mathrm{SC} \equiv \mathrm{N}) 2051 \mathrm{~cm}^{-1}$.

Physical Measurements and Instrumentation.-The UV-VIS spectra were recorded on a Milton Roy Spectronic 3000 diodearray spectrophotometer and steady-state emission spectra on a SPEX Fluorolog-2 spectrofluorometer. Lifetime measurements were performed with a Quanta Ray DCR-3 Nd-YAG laser (pulse output $355 \mathrm{~nm}, 8 \mathrm{~ns}$ ). Solutions for photochemical experiments were degassed by at least four freeze-pump-thaw cycles.

$X$-Ray Crystallography.- $\left[\mathrm{Au}_{3}(\mathrm{dpmp})_{2}\right][\mathrm{SCN}]_{3} . \quad \mathrm{X}-\mathrm{Ray}$ diffraction data were collected on a Nonius CAD 4 diffractometer using the $\theta-2 \theta$ scan mode $\left[2 \theta_{\max }=44.9^{\circ}\right.$, scan speed $\left.(16.48 / 7)-(16.48 / 2)^{\circ} \mathrm{min}^{-1}\right]$ at National Taiwan University. The unit cell dimensions were obtained from 25 reflections in the range $20<2 \theta<30.5^{\circ}$

Crystal data. $M=1778.12$ monoclinic, space group $P 2_{1} / n$, $a=12.474(4), b=25.575(4), c=20.182(6) \AA, \beta=92.61(3)^{\circ}$, $U=6432(3) \AA^{3}, \lambda=0.71069 \AA, Z=4, D_{\mathrm{c}}=1.836 \mathrm{~g} \mathrm{~cm}^{-3}$, crystal dimensions $0.20 \times 0.20 \times 0.20 \mathrm{~mm}, \mu(\mathrm{Mo}-\mathrm{K} \alpha)=7.09$ $\mathrm{mm}^{-1}, F(000)=3423$.

The last least-squares cycle was calculated with 140 atoms, 740 parameters and $5716\left(\left|I_{\mathrm{o}}\right|>2 \sigma\left|I_{\mathrm{o}}\right|\right)$ out of 8386 unique reflections; $R=0.042, R^{\prime}=0.035, w=1 / \sigma^{2}\left(F_{\mathrm{o}}\right)$. The final Fourier difference map showed residual extrema in the range 1.65 to -1.13 e $\AA^{-3}$

$\left[\mathrm{Au}_{4}(\mathrm{dpmp})_{2}(\mathrm{SCN})_{2}\right][\mathrm{SCN}] \mathrm{Cl}$. The complex was obtained as golden-yellow flat prisms. 
Table 1 Atomic parameters of non-hydrogen atoms of $\left[\mathrm{Au}_{3}(\mathrm{dpmp})_{2}\right][\mathrm{SCN}]_{3}$

\begin{tabular}{|c|c|c|c|c|c|c|c|}
\hline Atom & $x$ & $y$ & $z$ & Atom & $x$ & $y$ & $z$ \\
\hline $\mathrm{Au}(1)$ & $0.23831(3)$ & $0.36688(2)$ & $0.86636(2)$ & $\mathrm{C}(3 \mathrm{~F})$ & $-0.0422(11)$ & $0.4297(5)$ & $1.0751(7)$ \\
\hline $\mathrm{Au}(2)$ & $0.24893(3)$ & $0.24917(2)$ & $0.86435(2)$ & $\mathrm{C}(4 \mathrm{~F})$ & $0.0337(12)$ & $0.4683(5)$ & $1.0853(6)$ \\
\hline $\mathrm{Au}(3)$ & $0.25557(4)$ & $0.13434(2)$ & $0.89518(3)$ & $\mathrm{C}(5 \mathrm{~F})$ & $0.1213(10)$ & $0.4731(5)$ & $1.0477(7)$ \\
\hline$P(1)$ & $0.4147(2)$ & $0.3614(1)$ & $0.8371(2)$ & $\mathrm{C}(6 \mathrm{~F})$ & $0.1321(10)$ & $0.4385(5)$ & $0.9948(6)$ \\
\hline $\mathrm{P}(2)$ & $0.4321(2)$ & $0.2441(1)$ & $0.8598(2)$ & $C(1 G)$ & $-0.0373(8)$ & $0.3875(4)$ & $0.8490(5)$ \\
\hline$P(3)$ & $0.4385(2)$ & $0.1356(1)$ & $0.9194(2)$ & $C(2 G)$ & $-0.0171(9)$ & $0.4007(5)$ & $0.7855(6)$ \\
\hline$P(4)$ & $0.0671(2)$ & $0.3631(1)$ & $0.9057(2)$ & $C(3 G)$ & $-0.0963(12)$ & $0.4166(6)$ & $0.7402(7)$ \\
\hline$P(5)$ & $0.0647(2)$ & $0.2491(1)$ & $0.8664(1)$ & $C(4 G)$ & $-0.1990(11)$ & $0.4209(5)$ & $0.7605(7)$ \\
\hline$P(6)$ & $0.0748(2)$ & $0.1304(1)$ & $0.8640(2)$ & $C(5 G)$ & $-0.2223(10)$ & $0.4087(5)$ & $0.8225(7)$ \\
\hline$C(1 \mathrm{~A})$ & $0.4931(9)$ & $0.4193(4)$ & $0.8610(6)$ & $C(6 G)$ & $-0.1420(9)$ & $0.3918(4)$ & $0.8683(6)$ \\
\hline$C(2 A)$ & $0.5334(11)$ & $0.4253(5)$ & $0.9236(7)$ & $\mathrm{C}(\mathbf{1 H})$ & $0.0009(9)$ & $0.2652(4)$ & $0.7875(5)$ \\
\hline$C(3 A)$ & $0.5856(11)$ & $0.4707(5)$ & $0.9442(7)$ & $\mathrm{C}(2 \mathrm{H})$ & $-0.1092(10)$ & $0.2735(5)$ & $0.7793(6)$ \\
\hline$C(4 A)$ & $0.5958(11)$ & $0.5094(5)$ & $0.8985(8)$ & $\mathrm{C}(3 \mathrm{H})$ & $-0.1525(10)$ & $0.2873(5)$ & $0.7185(7)$ \\
\hline$C(5 A)$ & $0.5565(11)$ & $0.5045(5)$ & $0.8343(9)$ & $\mathrm{C}(4 \mathrm{H})$ & $-0.0919(13)$ & $0.2926(5)$ & $0.6649(7)$ \\
\hline$C(6 A)$ & $0.5030(10)$ & $0.4591(4)$ & $0.8150(7)$ & $\mathrm{C}(5 \mathrm{H})$ & $0.0169(12)$ & $0.2842(5)$ & $0.6713(6)$ \\
\hline$C(1 B)$ & $0.4292(9)$ & $0.3512(4)$ & $0.7493(5)$ & $\mathrm{C}(6 \mathrm{H})$ & $0.0625(10)$ & $0.2709(4)$ & $0.7331(6)$ \\
\hline$C(2 B)$ & $0.5299(10)$ & $0.3469(4)$ & $0.7234(6)$ & $C(1 \mathrm{I})$ & $0.0538(8)$ & $0.1322(4)$ & $0.7760(6)$ \\
\hline $\mathrm{C}(3 \mathrm{~B})$ & $0.5411(12)$ & $0.3360(5)$ & $0.6573(7)$ & $\mathrm{C}(2 \mathrm{I})$ & $-0.0484(9)$ & $0.1423(4)$ & $0.7457(6)$ \\
\hline$C(4 B)$ & $0.4509(14)$ & $0.3290(5)$ & $0.6173(7)$ & $C(3 I)$ & $-0.0599(11)$ & $0.1471(4)$ & $0.6777(6)$ \\
\hline $\mathrm{C}(5 \mathrm{~B})$ & $0.3490(13)$ & $0.3339(6)$ & $0.6401(7)$ & $C(4 I)$ & $0.0233(13)$ & $0.1419(6)$ & $0.6375(7)$ \\
\hline$C(6 B)$ & $0.3390(10)$ & $0.3456(5)$ & $0.7075(6)$ & $\mathrm{C}(5 \mathrm{I})$ & $0.1224(11)$ & $0.1308(6)$ & $0.6665(7)$ \\
\hline$C(1 C)$ & $0.4817(9)$ & $0.2222(4)$ & $0.7829(6)$ & $C(6 I)$ & $0.1379(10)$ & $0.1258(5)$ & $0.7354(6)$ \\
\hline $\mathrm{C}(2 \mathrm{C})$ & $0.5930(9)$ & $0.2150(4)$ & $0.7747(6)$ & $\mathrm{C}(1 \mathrm{~J})$ & $-0.0009(9)$ & $0.0755(4)$ & $0.8929(6)$ \\
\hline$C(3 C)$ & $0.6286(10)$ & $0.1985(5)$ & $0.7151(7)$ & $\mathrm{C}(2 \mathrm{~J})$ & $0.0273(12)$ & $0.0267(5)$ & $0.8705(7)$ \\
\hline$C(4 C)$ & $0.5575(13)$ & $0.1883(5)$ & $0.6622(7)$ & $C(3 J)$ & $-0.0289(13)$ & $-0.0176(5)$ & $0.8908(8)$ \\
\hline$C(5 C)$ & $0.4494(11)$ & $0.1952(5)$ & $0.6699(6)$ & $\mathrm{C}(4 \mathrm{~J})$ & $-0.1090(11)$ & $-0.0124(5)$ & $0.9326(7)$ \\
\hline$C(6 C)$ & $0.4116(9)$ & $0.2114(4)$ & $0.7285(6)$ & $\mathrm{C}(5 \mathrm{~J})$ & $-0.1354(11)$ & $0.0351(6)$ & $0.9552(8)$ \\
\hline$C(1 D)$ & $0.4803(9)$ & $0.1036(4)$ & $0.9958(6)$ & $\mathrm{C}(6 \mathrm{~J})$ & $-0.0821(10)$ & $0.0787(5)$ & $0.9354(7)$ \\
\hline$C(2 D)$ & $0.5790(11)$ & $0.1125(5)$ & $1.0273(6)$ & $C(1)$ & $0.4916(9)$ & $0.3088(4)$ & $0.8779(6)$ \\
\hline$C(3 D)$ & $0.6146(11)$ & $0.0815(5)$ & $1.0803(7)$ & $C(2)$ & $0.4899(8)$ & $0.2030(4)$ & $0.9260(5)$ \\
\hline$C(4 D)$ & $0.5522(12)$ & $0.0423(5)$ & $1.1019(6)$ & $C(3)$ & $0.0225(8)$ & $0.2968(4)$ & $0.9265(6)$ \\
\hline$C(5 D)$ & $0.4513(12)$ & $0.0331(5)$ & $1.0719(6)$ & $\mathrm{C}(4)$ & $0.0072(8)$ & $0.1878(4)$ & $0.8958(5)$ \\
\hline$C(6 D)$ & $0.4171(10)$ & $0.0646(5)$ & $1.0187(6)$ & $C(5)$ & $0.2431(9)$ & $0.4790(6)$ & $0.7634(6)$ \\
\hline$C(1 E)$ & $0.5141(9)$ & $0.1038(4)$ & $0.8576(5)$ & $C(6)$ & $0.2490(10)$ & $0.2528(7)$ & $0.4682(8)$ \\
\hline $\mathrm{C}(2 \mathrm{E})$ & $0.6284(10)$ & $0.1026(4)$ & $0.8611(6)$ & $C(7)$ & $0.2291(10)$ & $0.2233(6)$ & $0.0201(5)$ \\
\hline$C(3 E)$ & $0.6832(10)$ & $0.0776(5)$ & $0.8133(7)$ & $S(1)$ & $0.2232(3)$ & $0.4803(2)$ & $0.8424(2)$ \\
\hline$C(4 E)$ & $0.6305(11)$ & $0.0542(5)$ & $0.7605(7)$ & $S(2)$ & $0.2212(5)$ & $0.2025(2)$ & $0.5119(3)$ \\
\hline$C(5 E)$ & $0.5204(12)$ & $0.0537(5)$ & $0.7572(6)$ & $S(3)$ & $0.2912(6)$ & $0.2866(3)$ & $0.0179(3)$ \\
\hline $\mathrm{C}(6 \mathrm{E})$ & $0.4629(9)$ & $0.0790(4)$ & $0.8041(6)$ & $\mathrm{N}(1)$ & $0.2588(10)$ & $0.4827(6)$ & $0.7102(7)$ \\
\hline$C(1 F)$ & $0.0568(9)$ & $0.3997(4)$ & $0.9819(6)$ & $\mathrm{N}(2)$ & $0.2651(10)$ & $0.2854(6)$ & $0.4379(8)$ \\
\hline $\mathrm{C}(2 \mathrm{~F})$ & $-0.0289(11)$ & $0.3958(4)$ & $1.0221(6)$ & $\mathrm{N}(3)$ & $0.2038(11)$ & $0.1942(7)$ & $0.0232(6)$ \\
\hline
\end{tabular}

Crystal data $M=2010.61$, triclinic, space group $P \overline{1}$ (no. 2$)$, $a=13.799(2), b=14.061(2), c=19.390(4) \AA, \alpha=88.46(2)$, $\beta=75.41(1), \gamma=74.58(1)^{\circ}, U=3506.4(1) \AA^{3}, D_{\mathrm{c}}=1.90 \mathrm{~g}$ $\mathrm{cm}^{-3}, Z=2, \mu(\mathrm{Mo}-\mathrm{K} \alpha)=86.16 \mathrm{~cm}^{-1}, F(000)=1904$, dimensions $0.14 \times 0.36 \times 0.34 \mathrm{~mm}$.

Intensities ( $h, \pm k, \pm l ; 12925$ unique data) were measured at $22^{\circ} \mathrm{C}$ on a Nicolet $\mathrm{R} 3 \mathrm{~m}$ four-circle diffractometer (graphitemonochromatized Mo-K $\alpha$ radiation, $\lambda=0.71073 \AA$ ) using the $\omega-2 \theta$ variable-scan $\left(3.30-15.60^{\circ} \mathrm{min}^{-1}\right)$ technique at the Chinese University of Hong Kong. Azimuthal scans of selected strong reflections over a range of $2 \theta$ values were used to define a pseudo-ellipsoid for the application of absorption corrections $(\mu r=0.14$, transmission factors $0.244-0.989)$.

Atomic coordinates for the $\mathrm{Au}$ atoms were deduced from a sharpened Patterson function, and the other non-hydrogen atoms were located from subsequent Fourier difference maps. All non-hydrogen atoms were refined anisotropically. All computations were performed on a Data General Nova $3 / 12$ minicomputer with the SHELXTL programs. ${ }^{8}$ Convergence for 7008 obtained data $\left(\left|F_{\mathrm{o}}\right| \geqslant 6 \sigma\left|F_{\mathrm{o}}\right|\right)$ and 691 variables was reached at $R=0.064, R_{\mathrm{G}}=0.076$ and $S=2.20$ with a weighting scheme $w=\left[\sigma^{2}\left(F_{\mathrm{o}}\right)+0.0004\left|F_{\mathrm{o}}\right|^{2}\right]^{-1}$. The final Fourier difference map showed residual extrema in the range 0.71 to $-0.62 \mathrm{e} \AA^{-3}$.

Tables 1 and 2 list the atomic coordinates of non-hydrogen atoms in each complex. Selected bond distances and angles are given in Table 3.
Additional material available from the Cambridge Crystallographic Data Centre comprises $\mathrm{H}$-atom coordinates, thermal parameters and remaining bond lengths and angles.

\section{Results and Discussion}

The ligand dpmp was first employed by Balch and coworkers ${ }^{5,9}$ for the synthesis of polynuclear $\mathrm{d}^{8}$ metal complexes. Recently, we have reported the formation of trinuclear $\mathrm{d}^{10}$ metal complexes 2 and 3 which display photoluminescent properties with this ligand. ${ }^{1 c, e}$ Reduction of $\left[\mathrm{AuCl}_{4}\right]^{-}$by $2,2^{\prime}-$ thiodiethanol in methanol generated $\mathrm{Au}^{\mathrm{I}}$ in situ, which rapidly reacted with dpmp. When the reaction was monitored by UVVIS absorption spectroscopy a species having $\lambda_{\max }$ at $\approx 350$ $\mathrm{nm}$ was formed in the early stages. Attempts to obtain it in pure form were unsuccessful as it is always contaminated with some $\left[\mathrm{Au}_{3}(\mathrm{dpmp})_{2}\right][\mathrm{SCN}]_{3}$. In one instance we were able to obtain crystals of this species, and the structure has been determined to be $\left[\mathrm{Au}_{4}(\mathrm{dpmp})_{2}(\mathrm{SCN})_{2}\right][\mathrm{SCN}] \mathrm{Cl}$. The $\left[\mathrm{Au}_{4}-\right.$ $\left.(\mathrm{dpmp})_{2}(\mathrm{SCN})_{2}\right]^{2+}$ ion is unstable in solution and is easily converted into $\left[\mathrm{Au}_{3}(\mathrm{dpmp})_{2}\right]^{3+}$ which is isolated as a $\mathrm{SCN}^{-}$ salt. The IR spectrum of $\left[\mathrm{Au}_{3}(\mathrm{dpmp})_{2}\right][\mathrm{SCN}]_{3}$ displays $v(\mathrm{SC} \equiv \mathrm{N})$ at $2051 \mathrm{~cm}^{-1}$ which is characteristic of a non-coordinating $\mathrm{SCN}^{-}$anion. The $v(\mathrm{SC} \equiv \mathrm{N})$ frequency of metalbound thiocyanate occurs at $2170-2135 \mathrm{~cm}^{-1}$. The ${ }^{31} \mathrm{P}$ NMR spectrum (acetonitrile, relative to $\mathrm{H}_{3} \mathrm{PO}_{4}$ ) shows only two 
Table 2 Atomic coordinates $\left(\times 10^{5}\right.$ for $\mathrm{Au}, \times 10^{4}$ for others $)$ for non-hydrogen atoms of $\left[\mathrm{Au}_{4}(\mathrm{dpmp})_{2}(\mathrm{SCN})_{2}\right][\mathrm{SCN}] \mathrm{Cl}$

\begin{tabular}{|c|c|c|c|c|c|c|c|}
\hline Atom & $x$ & $y$ & $z$ & Atom & $x$ & $y$ & $z$ \\
\hline $\mathrm{Au}(1)$ & $28602(8)$ & $-6299(7)$ & $21142(6)$ & $C(33)$ & -3701 & 7544 & 4757 \\
\hline $\mathrm{Au}(2)$ & $12570(6)$ & $14629(6)$ & $24828(5)$ & $C(34)$ & -2904 & 7374 & 5104 \\
\hline $\mathrm{Au}(3)$ & $2705(6)$ & $36732(6)$ & $24169(5)$ & $C(35)$ & -1979 & 6646 & 4835 \\
\hline $\mathrm{Au}(4)$ & $-10930(7)$ & $57705(7)$ & $22150(6)$ & $C(36)$ & -1853 & 6088 & 4218 \\
\hline$P(1)$ & $3756(5)$ & $-300(4)$ & $2858(4)$ & $C(37)$ & $-3618(10)$ & $5819(12)$ & $2732(9)$ \\
\hline $\mathbf{P}(2)$ & $2819(4)$ & $1788(4)$ & $2465(3)$ & $\mathrm{C}(38)$ & -4515 & 5564 & 3100 \\
\hline$P(3)$ & $1844(4)$ & $3994(4)$ & $2367(3)$ & $C(39)$ & -5397 & 5809 & 2835 \\
\hline$P(4)$ & $-2452(4)$ & $5522(4)$ & $3051(3)$ & $C(40)$ & -5382 & 6308 & 2203 \\
\hline$P(5)$ & $-1352(4)$ & $3398(4)$ & $2607(3)$ & $C(41)$ & -4485 & 6563 & 1835 \\
\hline$P(6)$ & $-318(4)$ & $1191(4)$ & $2463(3)$ & $C(42)$ & -3603 & 6318 & 2099 \\
\hline$C(1)$ & $3558(15)$ & $-848(15)$ & $3702(10)$ & $C(43)$ & $-1923(10)$ & $3551(10)$ & $1844(7)$ \\
\hline$C(2)$ & 3604 & -397 & 4320 & $C(44)$ & -2919 & 3432 & 1936 \\
\hline$C(3)$ & 3479 & -881 & 4961 & $C(45)$ & -3383 & 3565 & 1366 \\
\hline$C(4)$ & 3309 & -1817 & 4983 & $C(46)$ & -2851 & 3816 & 705 \\
\hline$C(5)$ & 3263 & -2269 & 4364 & $C(47)$ & -1856 & 3935 & 613 \\
\hline$C(6)$ & 3388 & -1784 & 3724 & $C(48)$ & -1391 & 3802 & 1183 \\
\hline$C(7)$ & $5155(9)$ & $-676(11)$ & $2451(11)$ & $C(49)$ & $-471(14)$ & $1127(11)$ & $1565(9)$ \\
\hline $\mathrm{C}(8)$ & 5824 & -754 & 2895 & $C(50)$ & -1359 & 954 & 1433 \\
\hline$C(9)$ & 6897 & -1058 & 2609 & $C(51)$ & -1479 & 979 & 739 \\
\hline$C(10)$ & 7301 & -1283 & 1879 & $C(52)$ & -711 & 1176 & 177 \\
\hline$C(11)$ & 6632 & -1205 & 1435 & $C(53)$ & 178 & 1348 & 309 \\
\hline$C(12)$ & 5559 & -901 & 1722 & C(54) & 297 & 1324 & 1003 \\
\hline$C(13)$ & $3785(12)$ & $1564(11)$ & $1596(9)$ & $C(55)$ & $-554(13)$ & $98(12)$ & $2854(12)$ \\
\hline$C(14)$ & 4780 & 1678 & 1522 & $C(56)$ & -829 & 98 & 3597 \\
\hline$C(15)$ & 5480 & 1555 & 851 & $C(57)$ & -995 & -751 & 3940 \\
\hline$C(16)$ & 5186 & 1319 & 254 & $\mathrm{C}(58)$ & -886 & -1600 & 3540 \\
\hline$C(17)$ & 4191 & 1206 & 327 & $C(59)$ & -611 & -1599 & 2796 \\
\hline$C(18)$ & 3491 & 1329 & 998 & $C(60)$ & -445 & -750 & 2453 \\
\hline$C(19)$ & $2637(10)$ & $4067(10)$ & $1478(7)$ & $C(61)$ & $3446(18)$ & $1041(14)$ & $3098(13)$ \\
\hline$C(20)$ & 3600 & 4263 & 1383 & $\mathrm{C}(62)$ & $2625(14)$ & $3026(13)$ & $2839(11)$ \\
\hline $\mathrm{C}(21)$ & 4232 & 4265 & 697 & $\mathrm{C}(63)$ & $-2275(16)$ & $4220(14)$ & $3347(11)$ \\
\hline $\mathrm{C}(22)$ & 3900 & 4071 & 106 & $C(64)$ & $-1405(15)$ & $2173(13)$ & $2931(11)$ \\
\hline $\mathrm{C}(23)$ & 2937 & 3874 & 201 & $C(65)$ & $2811(28)$ & $-2175(23)$ & $1042(18)$ \\
\hline$C(24)$ & 2305 & 3872 & 887 & $C(66)$ & $-660(27)$ & $6460(27)$ & $665(22)$ \\
\hline$C(25)$ & $1694(11)$ & $5158(10)$ & $2833(10)$ & C(67) & 177(34) & $2650(23)$ & $4088(20)$ \\
\hline$C(26)$ & 1358 & 5153 & 3574 & $S(1)$ & $2092(6)$ & $-1051(6)$ & $1279(5)$ \\
\hline$C(27)$ & 1210 & 5999 & 3989 & $S(2)$ & $150(5)$ & $6205(6)$ & $1317(5)$ \\
\hline$C(28)$ & 1398 & 6852 & 3663 & $S(3)$ & $802(9)$ & $1625(9)$ & $4108(6)$ \\
\hline$C(29)$ & 1734 & 6857 & 2921 & $N(1)$ & $3303(27)$ & $-2964(19)$ & $865(16)$ \\
\hline$C(30)$ & 1882 & 6010 & 2507 & $N(2)$ & $-1152(40)$ & $6873(54)$ & $336(30)$ \\
\hline$C(31)$ & $-2650(13)$ & $6258(11)$ & $3871(8)$ & $\mathrm{N}(3)$ & $-248(24)$ & $3429(24)$ & $4119(13)$ \\
\hline$C(32)$ & -3575 & 6986 & 4141 & $\mathrm{Cl}$ & $5897(9)$ & $1648(8)$ & $3246(7)$ \\
\hline
\end{tabular}

types of phosphorus nuclei in a ratio $2: 1[\delta 35.04(2 \mathrm{P})$ and 30.36 (1P)]. The signal at $\delta 35.04$ is assigned to atoms $P(1)$ and $P(3)$ whereas that at $\delta 30.36$ is due to $P(2)$ (see Fig. 1 for atom numbering). Since the chemical shifts of atoms $P(1)$ and $P(3)$ and that of the $\mathrm{P}$ atoms in $\left[\mathrm{Au}_{2}(\mathrm{dppm})_{2}\right]^{2+}[\mathrm{dppm}=$ bis(diphenylphosphino)methane $]^{1 a}$ are virtually identical, the NMR data are consistent with the $X$-ray results in that the $\mathrm{SCN}^{-}$ion does not bind to the Au atoms. In solution, the major species present is $\left[\mathrm{Au}_{3}(\mathrm{dpmp})_{2}\right]^{3+}$

Crystal Structure of $\left[\mathrm{Au}_{3}(\mathrm{dpmp})_{2}\right]^{3+}$.- Fig. 1 shows a perspective view of the complex cation. The cation consists of three $\mathrm{d}^{10} \mathrm{P}_{2} \mathrm{Au}^{1}$ units held together by the two bridging dpmp ligands. The three $\mathrm{SCN}^{-}$ions can be considered as uncoordinated as the Au ...SCN distances range from 2.947(4) to $3.717(7) \AA$. The most interesting structural feature is that the $\mathrm{Au}_{3}$ chain is in a nearly linear array in contrast to most trinuclear gold(I) complexes where a bent $\mathrm{Au}_{3}$ chain is observed. The $\mathrm{Au}-\mathrm{Au}-\mathrm{Au}$ angle, $167.21(2)^{\circ}$, is closer to the ideal value of $180^{\circ}$ than that of $136.26(4)^{\circ}$ found in $\left[\mathrm{Au}_{3}(\mathrm{dmmp})_{2}\right]^{3+} 4$ $[\mathrm{dmmp}=\text { bis(dimethylphosphinomethyl)methylphosphine }]^{1 b}$ and $110.9(1)^{\circ}$ in $\left[\mathrm{Au}_{3} \mathrm{Cl}_{3}(\mu\right.$-dpma) $][$ dpma $=$ bis(diphenylphosphinomethyl)phenylarsine $].{ }^{10}$ It is also larger than the $\mathrm{Rh}-\mathrm{Rh}-\mathrm{Rh}$ angle in $1\left[160.2(1)^{\circ}\right],{ }^{5}$ although smaller than the $\mathrm{Ag}-\mathrm{Ag}-\mathrm{Ag}$ angle of $175.33(7)^{\circ}$ in $2^{1 c}$ This structure can thus serve as a model for a linear trinuclear gold(I) complex. The $\mathbf{P}_{2} \mathbf{A u}$ units are linear with $\mathbf{P}-\mathbf{A u}-\mathbf{P}$ bond angles being 172.2(1), 176.1(1) and $176.5(1)^{\circ}$. Similar P-Au-P angles have been found in $4\left[175.7(2)^{\circ}\right]^{1 b}$ and in $\left[\mathrm{Au}_{2}\right.$ $\left.(\mathrm{dppm})_{2}\right]^{2+}\left[175.2(2)^{\circ}\right] \cdot{ }^{11}$ The intramolecular $\mathrm{Au}-\mathrm{Au}$ distances of $3.0137(8)$ and $3.0049(8) \AA$ are comparable to those in $\left[\mathrm{Au}_{2}(\mathrm{dmpm})_{2}\right]^{2+}[3.028(2) \AA][\mathrm{dmpm}=$ bis(dimethylphosphino)methane $],{ }^{12} 4[2.981(1) \text { and } 2.962(1) \AA]^{1 b}$ and $\left[\mathrm{Au}_{2}\right.$ $\left.(\mathrm{dppm})_{2}\right]^{2+}[2.982(2) \AA],{ }^{11}$ but shorter than those of 3.201(1)-3.420(1) $\AA$ in $\left[\mathrm{Au}_{3}\left\{\mathrm{HC}\left(\mathrm{PPh}_{2}\right)_{3}\right\} \mathrm{X}_{3}\right] .^{13}$ According to Schmidbaur and co-workers ${ }^{13}$ such short intermetallic Au $\cdots A$ Au contacts suggest the operation of weak metal-metal interactions. The $\mathrm{Au}-\mathrm{Au}$ interaction is certainly attractive and spectroscopically significant. The $\mathrm{Au}-\mathrm{P}$ distances ranging from $2.295(3)$ to $2.315(3) \AA$ are normal.

Crystal Structure of $\left[\mathrm{Au}_{4}(\mathrm{dpmp})_{2}(\mathrm{SCN})_{2}\right]^{2+}$.-Fig. 2 shows the perspective view of the complex cation with atom numbering. The structure features one of the few examples of a nearly linear tetranuclear metal complex. It consists of four twoco-ordinated Au atoms which are bridged by two dpmp ligands. The measured $\mathrm{Au}-\mathrm{Au}-\mathrm{Au}$ angles of $160.0(1)$ and $167.2(1)^{\circ}$ are similar to that of $167.21(2)^{\circ}$ for $\left[\mathrm{Au}_{3}(\mathrm{dpmp})_{2}\right]^{3+}$ described above. They are, however, slightly smaller than the $R h-R h-R h$ angle of $168.0(1)^{\circ}$ in the isostructural $\left[\mathrm{Rh}_{4}(\mu-\mathrm{CO})(\mathrm{CO})_{2}(\mu-\right.$ 


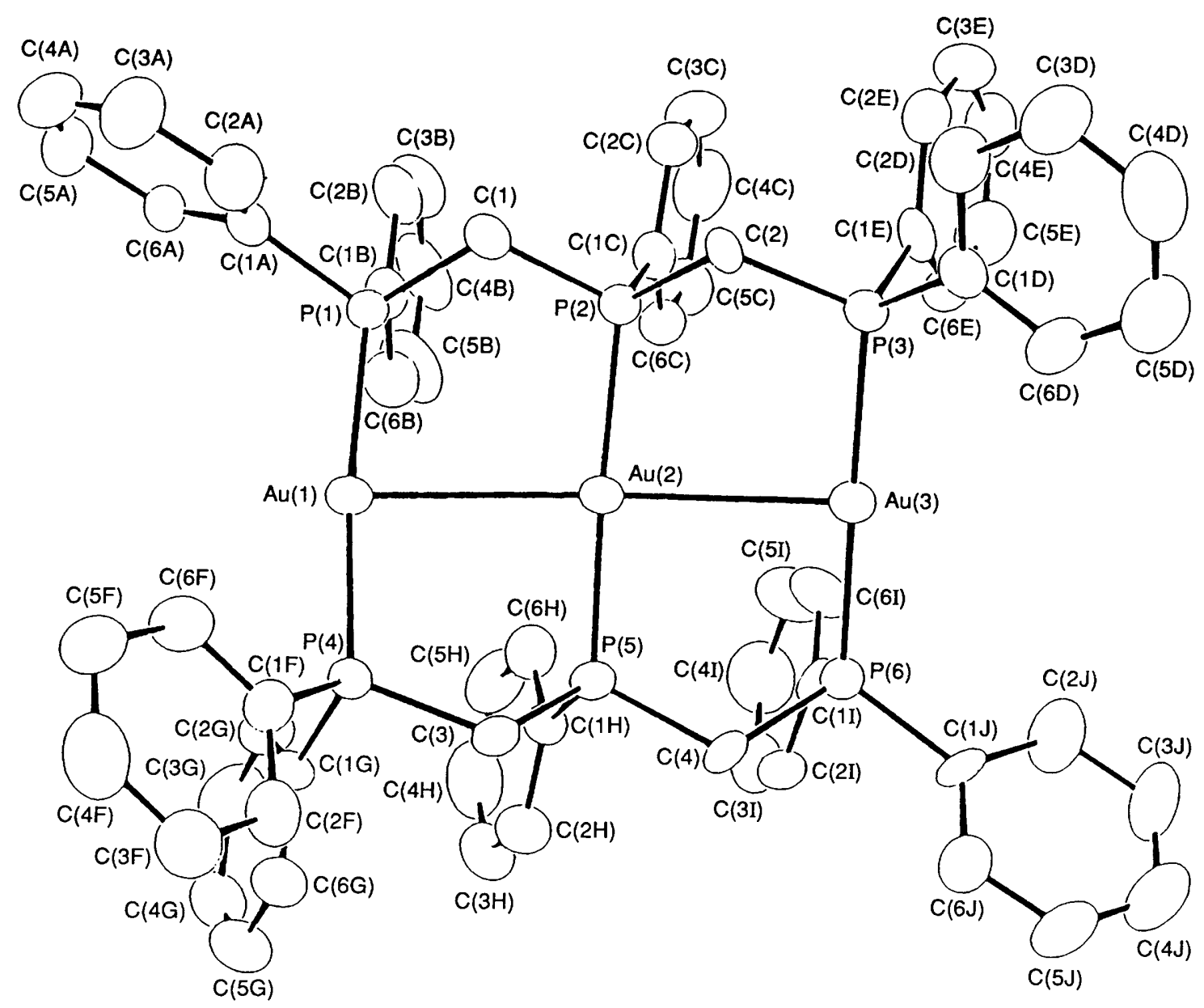

Fig. 1 An ORTEP plot of $\left[\mathrm{Au}_{3}(\mathrm{dpmp})_{3}\right]^{3+}$ with atom numbering

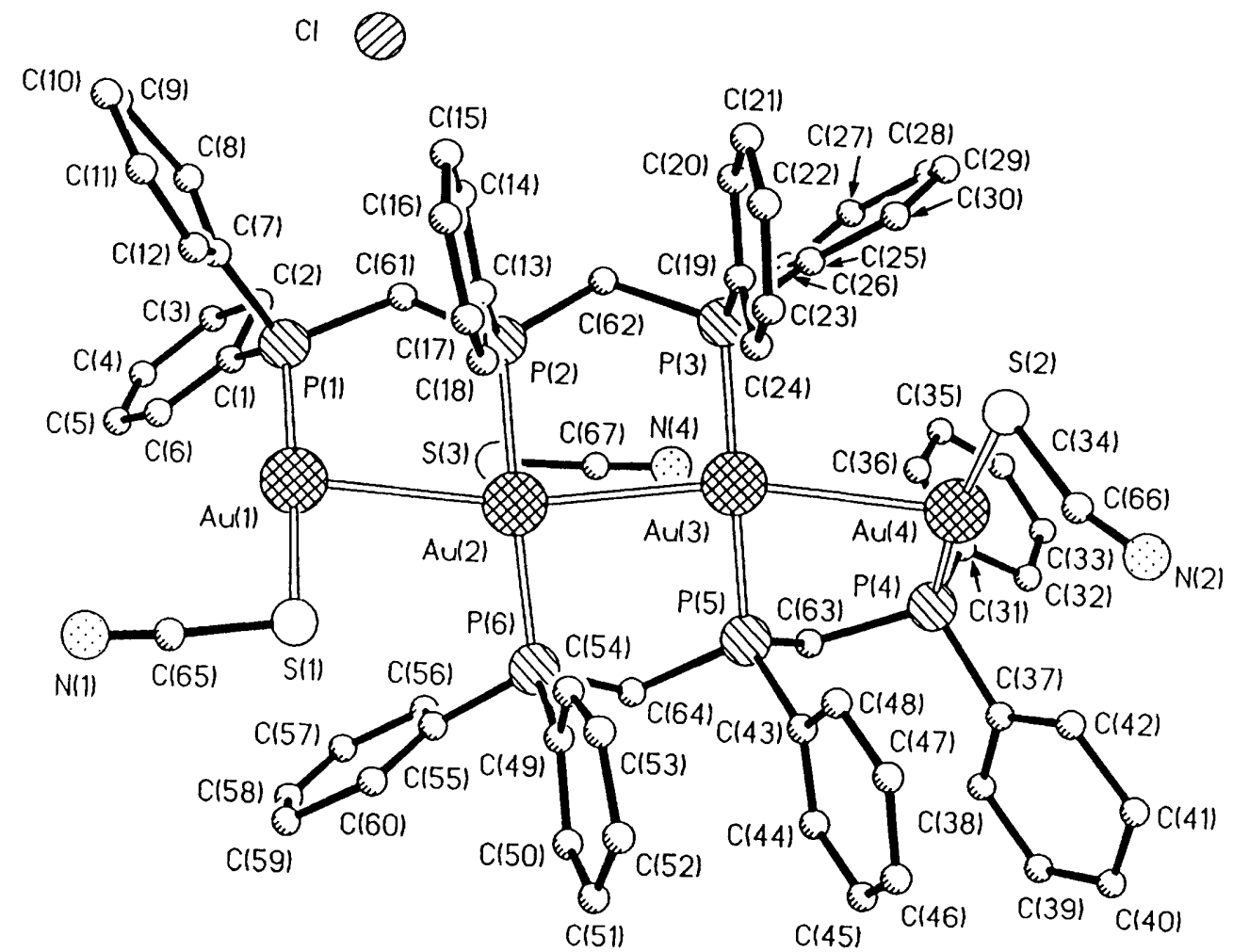

Fig. 2 An ORTEP plot of $\left[\mathrm{Au}_{4}(\mathrm{dpmp})_{2}(\mathrm{SCN})_{2}\right][\mathrm{SCN}] \mathrm{Cl}$ with atom numbering 
Table 3 Selected bond distances $(\AA)$ and angles ( $\left.{ }^{\circ}\right)$

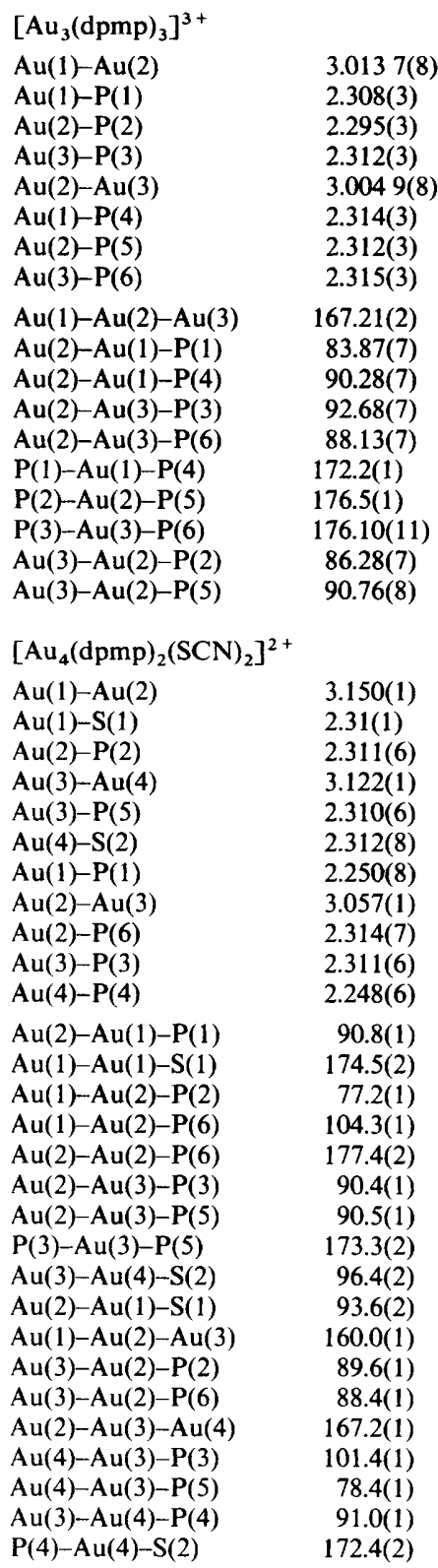

$\left.\mathrm{Cl})_{2} \mathrm{Cl}_{2}(\mathrm{dppy})_{2}\right][\mathrm{dppy}=2,6$-bis(diphenylphosphino)pyridine ${ }^{1{ }^{14}}$ In the related $\left[\mathrm{Au}_{4} \mathrm{Cl}_{2}(\mu \text {-dpma })_{2}\right]^{2+}$ system ${ }^{5}$ the $\mathrm{Au}_{4}$ chain is bent with a $\mathrm{Au}-\mathrm{Au}-\mathrm{Au}$ angle of $88.0(1)^{\circ}$. The bent $\mathrm{Au}_{4}$ chain has previously been attributed to $\mathrm{Au}-\mathrm{Au}$ bonding interaction. Perhaps the nearly linear $\mathrm{Au}_{3}$ and $\mathrm{Au}_{4}$ chains found in this work are due to the constraining effect of the dpmp ligand, which becomes an important factor in affecting the structure. It should also be remembered that the $\mathrm{Au}^{\mathrm{I}}-\mathrm{Au}^{\mathrm{I}}$ interaction is weak. The measured $\mathrm{Au}(2)-\mathrm{Au}(3)$ distance of $3.057(1) \AA$ is similar to that for $\left[\mathrm{Au}_{3}(\mathrm{dpmp})_{2}\right]^{3+}$ as discussed above. The $\mathrm{Au}(1)-\mathrm{Au}(2)$ and $\mathrm{Au}(3)-\mathrm{Au}(4)$ distances of 3.150(1) and $3.122(1) \AA$ are slightly larger, perhaps due to the coordination of $\mathrm{SCN}^{-}$to atoms $\mathrm{Au}(1)$ and $\mathrm{Au}(4)$. Because $\mathrm{Au}^{\mathrm{I}}$ is considered to be soft, it is not unreasonable to find that the $\mathrm{SCN}^{-}$ligand is $S$-bonded to the Au atoms. The $\mathrm{Au}-\mathrm{P}$ and $\mathrm{Au}-\mathrm{S}$ distances are normal.

Spectroscopic and Photophysical Properties.-Fig. 3 shows the room-temperature UV-VIS absorption spectra of [Au-

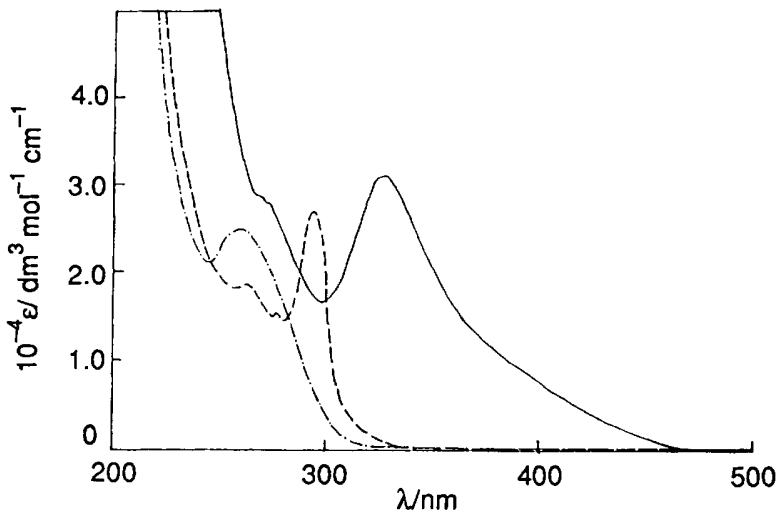

Fig. 3 The UV-VIS absorption spectra of $\left[\mathrm{Au}\left(\mathrm{PPh}_{3}\right)_{2}\right]\left[\mathrm{CF}_{3} \mathrm{SO}_{3}\right]$ $(-\cdot-\cdot-\cdot),\left[\mathrm{Au}_{2}(\mathrm{dppm})_{2}\right]\left[\mathrm{CF}_{3} \mathrm{SO}_{3}\right]_{2}(\ldots)$ and $\left[\mathrm{Au}_{3}(\mathrm{dpmp})_{2}\right]$ $[\mathrm{SCN}]_{3}(-)$ in acetonitrile at room temperature

$\left.\left(\mathrm{PPh}_{3}\right)_{2}\right]\left[\mathrm{CF}_{3} \mathrm{SO}_{3}\right], \quad\left[\mathrm{Au}_{2}(\mathrm{dppm})_{2}\right]\left[\mathrm{CF}_{3} \mathrm{SO}_{3}\right]_{2}$ and $\left[\mathrm{Au}_{3}-\right.$ $\left.(\mathrm{dpmp})_{2}\right][\mathrm{SCN}]_{3}$ in acetonitrile. The corresponding spectrum of a crystal of $\left[\mathrm{Au}_{4}(\mathrm{dpmp})_{2}(\mathrm{SCN})_{2}\right][\mathrm{SCN}] \mathrm{Cl}$ recorded in one instance showed a broad absorption band at $\approx 350$ $\mathrm{nm}$. The spectra are dominated by the intense absorption at $\lambda_{\max }=259 \mathrm{~nm}\left(\varepsilon_{\max }=2.5 \times 10^{4}\right)$ for $\left[\mathrm{Au}\left(\mathrm{PPh}_{3}\right)_{2}\right]^{+}, 295$ $\left(\varepsilon_{\max }=2.72 \times 10^{4}\right)$ for $\left[\mathrm{Au}_{2}(\mathrm{dppm})_{2}\right]^{2+}, 326\left(\varepsilon_{\max }=3.16\right.$ $\left.\times 10^{4} \mathrm{dm}^{3} \mathrm{~mol}^{-1} \mathrm{~cm}^{-1}\right)$ for $\left[\mathrm{Au}_{3}(\mathrm{dpmp})_{2}\right]^{3+}, 350 \mathrm{~nm}$ for $\left[\mathrm{Au}_{4}(\mathrm{dpmp})_{2}(\mathrm{SCN})_{2}\right]^{2+}$.

The molecular orbital diagram for bi- and tri-nuclear gold(I) phosphine systems has been discussed before. ${ }^{1 b}$ One would expect $\left[\mathrm{Au}_{4}(\mathrm{dpmp})_{2}(\mathrm{SCN})_{2}\right]^{2+}$ to have a similar diagram although the energy gap between the $p_{\sigma}$ and $d_{\delta^{*}}$ (or $d_{\sigma^{*}}$ ) orbitals is reduced. Here, the $p_{\sigma}\left(p_{\sigma^{*}}\right), d_{\sigma}\left(d_{\sigma^{*}}\right)$ and $d_{\delta}\left(d_{\delta^{*}}\right)$ orbitals come from the symmetric (antisymmetric) combination of the $6 \mathrm{p}_{z}, 5 \mathrm{~d}_{z^{2}}$ and $\left(\mathrm{d}_{x y}, \mathrm{~d}_{x^{2}-y^{2}}\right)$ orbitals respectively. The $\mathrm{Au}-\mathrm{Au}-\mathrm{Au}$ axis is defined to be the $\mathrm{Z}$ axis. It is likely that configurational mixing between the $\mathrm{p}_{\sigma}$ and $\pi^{*}(\mathrm{dpmp})$ orbitals may exist. For symmetry reasons, the $d_{\delta^{*}} \longrightarrow p_{\sigma}$ transition is expected to be less intense than that of $d_{\sigma^{*}} \longrightarrow p_{\sigma^{*}}$. The electronic absorption spectrum of $\left[\mathrm{Au}_{3}(\mathrm{dpmp})_{2}\right]^{3+}$ shows an intense band at $326 \mathrm{~nm}$ and a weaker one (shoulder) at around $350 \mathrm{~nm}$. By analogy to the well established pattern in $d^{8}-d^{8}$ species $^{5,15}$ and previous work on the related $\mathrm{d}^{10}-\mathrm{d}^{10}$ system, ${ }^{1 b}$ the intense band of $\left[\mathrm{Au}_{3}(\mathrm{dpmp})_{2}\right]^{3+}$ at $326 \mathrm{~nm}$ is attributed to the spin-allowed $d_{\sigma^{*}} \longrightarrow p_{\sigma}$ transition and the weaker one to the $d_{\delta^{*}} \longrightarrow p_{\sigma}$ transition. The stacking of $P_{2} A u$ units results in an attractive $\mathrm{Au}-\mathrm{Au}$ interaction. As the number of $\mathrm{P}_{2} \mathrm{Au}$ units increases the $d_{\sigma^{*}}-p_{\sigma}$ energy gap narrows and the energy of the $\mathrm{d}_{\mathrm{\sigma}^{*}}$ orbital increases. Thus it is not unreasonable to find that $\left[\mathrm{Au}_{4}(\mathrm{dpmp})_{2}(\mathrm{SCN})_{2}\right]^{2+}$ absorbs at a lower energy than does $\left[\mathrm{Au}_{3}(\mathrm{dpmp})_{2}\right]^{3+}$. A similar red shift in the $\mathrm{d}_{\sigma^{*}} \longrightarrow \mathrm{p}_{\sigma}$ transition has been reported in polynuclear $\mathrm{d}^{8}$ systems. ${ }^{1 b}$

The complex $\left[\mathrm{Au}_{4}(\mathrm{dpmp})_{2}(\mathrm{SCN})_{2}\right][\mathrm{SCN}] \mathrm{Cl}$ has been found to display an intense yellow emission upon UV-VIS excitation; however, its photophysical properties have not been investigated in detail because of the lack of a reliable synthesis of this complex. Upon excitation at $300-400 \mathrm{~nm}$ a degassed acetonitrile solution of $\left[\mathrm{Au}_{3}(\mathrm{dpmp})_{2}\right][\mathrm{SCN}]_{3}$ displays intense photoluminescence at room temperature. As shown in Fig. 4, there are two emissions centred at 600 and $500 \mathrm{~nm}$, the latter one appearing as a shoulder. The emission lifetimes have been measured to be 1.0 and $3.7 \mu \mathrm{s}$ for the high- and low-energy emissions respectively. Since the free dpmp ligand exhibits broad and weak emission from 420 to $500 \mathrm{~nm}$ in acetonitrile at room temperature, the emission at $500 \mathrm{~nm}$ likely comes from intraligand spin-forbidden transitions. The lowest-energy emitting electronic state is unlikely to be derived from the ${ }^{3}\left[\left(\mathrm{~d}_{\sigma^{*}}\right)^{1}\left(\mathrm{p}_{\sigma}\right)^{1}\right]$ state because of the relatively small difference in emission energies between $\left[\mathrm{Au}_{2}(\mathrm{dppm})_{2}\right]^{2+}$ (emission band centred at $570 \mathrm{~nm})^{1 a}$ and the present system, and the very large 


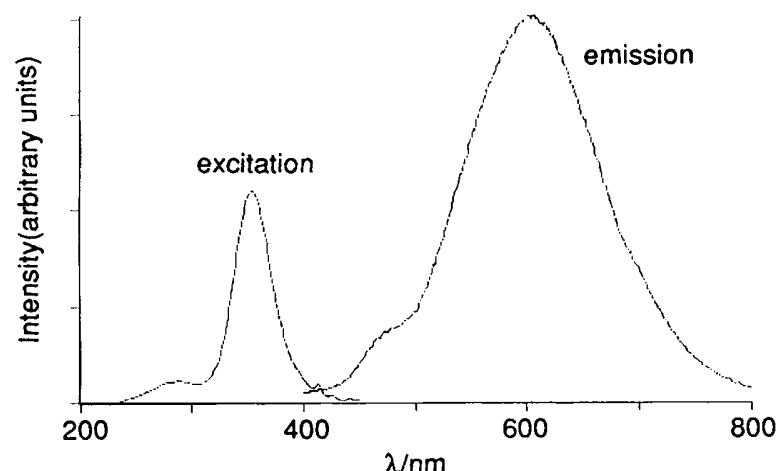

Fig. 4 Emission and excitation spectra of $\left[\mathrm{Au}_{3}(\mathrm{dpmp})_{2}\right][\mathrm{SCN}]_{3}$ in degassed acetonitrile at room temperature

Stokes shift observed between the $d_{\sigma^{*}} \longrightarrow p_{\sigma}$ transition energy and the emission at $600 \mathrm{~nm}$. We suggest that the latter emission of $\left[\mathrm{Au}_{3}(\mathrm{dpmp})_{2}\right]^{3+}$ comes from the low-lying ${ }^{3}\left[\left(\mathrm{~d}_{\delta^{*}}\right)^{1}\left(\mathrm{p}_{\sigma}\right)^{1}\right]$ state. Its quantum yield was measured to be $1.4 \times 10^{-3}$ (excited at $400 \mathrm{~nm}$ ). Similar emission (maximized at $610 \mathrm{~nm}$ ) could also be observed in a solid-state sample at room temperature. Cooling the sample to $77 \mathrm{~K}$ only leads to an increase in emission intensity. No vibrational fine structure has been observed.

\section{Acknowledgements}

We acknowledge support from the Hong Kong Research Grants council, the Croucher Foundation and the National Science Council of Taiwan. D. L. is grateful for a scholarship, administered by the Li Ka Shing Foundation, and C.-M. C. for a visiting Professorship, administered by the National Taiwan University.

\section{References}

1 (a) C. M. Che, H. L. Kwong, C. K. Poon and V. W. W. Yam, J. Chem. Soc., Dalton Trans., 1990, 3215; (b) V. W. W. Yam, T. F. Lai and C. M. Che, J. Chem. Soc. Dalton Trans., 1990, 3747; (c) C. M. Che, H. K. Yip, S. M. Peng, G. H. Lee, Y. M. Wang and S. T. Liu, J. Chem. Soc., Chem. Commun., 1991, 1615; (d) C. M. Che, H. K. Yip, V. W. W. Yam, P. Y. Cheung, T. F. Lai, S.-J. Shieh and S. M. Peng, J. Chem. Soc., Dalton Trans., 1992, 427; (e) D. Li, H. K. Yip, C. M. Che, Z. Y. Zhou, T. C. W. Mak and S. T. Liu, J. Chem. Soc., Datton Trans., 1992 2445 .

2 C. King, J. C. Wang, N. I. Md. Khan and J. P. Fackler, jun., Inorg. Chem., 1989, 28, 2145; N. I. Md. Khan, C. King, D. D. Heinrich, J. P. Fackler, jun. and L. C. Porter, Inorg. Chem., 1989, 28, 2150.

3 C. M. Che, W. T. Wong, T. F. Lai and H. L. Kwong, J. Chem. Soc., Chem. Commun., 1989, 243.

4 D. Perreault, M. Drouin, A. Michel and P. D. Harvey, Inorg. Chem., 1991, 30, 2

5 A. L. Balch, L. A. Fossett, J. K. Nagle and M. M. Olmstead, J. Am. Chem. Soc., 1988, 110, 6732

6 R. Appel, K. Geisler and H. F. Schöler, Chem. Ber., 1979, 112, 648

7 C. A. McAuliffe, R. V. Parish and P. D. Randall, J. Chem. Soc., Dalton Trans., 1979, 1730

8 G. M. Sheldrick, in Computational Crystallography, ed. D. Sayre, Oxford University Press, New York. 1982, p. 506.

9 R. R. Guimerans, M. M. Olmstead and A. L. Balch, J. Am. Chem. Soc., 1983, 105, 1677.

10 A. L. Balch, E. Y. Fung and M. M. Olmstead, J. Am. Chem. Soc., $1990,112,5181$

11 L. C. Porter, N. I. Md. Khan, C. King and J. P. Fackler, jun., Acta Crystallogr., Sect. C, 1989, 45, 947.

12 H. H. Karsch and U. Schubert, Z. Naturforsch., Teil B, 1982, 37, 186

13 A. Stützer, P. Bissinger and H. Schmidbaur, Chem. Ber., 1992, 125, 367.

14 F. E. Wood, M. M. Olmstead and A. L. Balch, J. Am. Chem. Soc., $1983,105,6332$.

15 D. M. Roundhill, H. B. Gray and C. M. Che, Acc. Chem. Res., 1989, 22,55 . 